\title{
The Political and Security Nexus of the Taiwan Strait and China's New Military Capabilities.
}

\section{Paul Irwin Crookes}

This article explores the political and security implications for relations between mainland China and Taiwan in light of the recent election of a new president in Taipei. Due to be inaugurated in May 2016, Tsai Ing-wen hails from a different point on the political spectrum to that of the outgoing leadership, introducing uncertainties in the political relationship with the mainland and casting light on the continuing importance of the United States as a security actor in the region. Concurrent with outlining the nature of this political change and the uncertainties this introduces, the article evaluates evidence of a shift in the balance of military power across the Taiwan Strait, potentially changing the dynamics of decision making for all sides in the event of future conflict.

The resounding election victory earlier this year for Tsai Ing-wen as Taiwan's new president along with the concurrent achievement of a legislative majority for her Democratic Progressive Party (DPP) presages a number of important uncertainties in the future direction of cross-strait relations which deserve to be more closely examined. ${ }^{1}$ Politically, this signals a shift of power from a presidential administration and parliament controlled by the Kuomintang (the Nationalist Party, or KMT) to a new era where both executive and legislature are now led by the DPP, with the party gaining control of Taiwan's parliament from the KMT for the first time ever. In the colour-coded nomenclature of Taiwan's vibrant domestic political spectrum, blue has been replaced by green. ${ }^{2}$ 
Yet there is much more to this change than just the ousting of the incumbent ruling party by the opposition. The DPP has long been regarded as more hostile towards promoting the type of closer relationship with mainland China that has been the centrepiece of outgoing president Ma Ying-jeou's cross-strait engagement policy over the last eight years of KMT rule, with the likely future character of such relations under the new administration now far less clear-cut than before. At the heart of current uncertainties - reinforced by the strength of Tsai's electoral mandate- is the DPP's attitude to the 1992 Consensus on the centrality of the 'one China' principle as the basis for cross-strait dialogue. In 2005, under the last DPP-led administration, relations with mainland China soured to the point where Beijing felt it necessary to enact its Anti-Secession Law to set out the legal basis for prompting military action over any future declaration of independence by Taiwan. ${ }^{3}$

The one China principle can be summarised as the declaration that there is only one China on both sides of the Taiwan Strait, that there can never be two Chinas, nor one China and one Taiwan, and that Taiwan is 'an inalienable part of China'. ${ }^{4}$ A carefully constructed consensus on this sensitive issue was agreed between Beijing and Taipei in November 1992 with the objective of enabling meaningful cross-strait dialogue to take place. The wording put forward by Taiwan's politicians at the time was that, whilst recognising the principle of one China, each side would take a different interpretation of what this actually meant, with the KMT asserting that Beijing gave tacit acceptance of this suggested approach at the time. ${ }^{5}$

It is certainly true that over the last twenty years, mainland China has used the scope of this agreement as the foundation for further talks between the two sides, first with dialogue via unofficial and nominally non-state agencies but subsequently via direct talks between 
officials and politicians, culminating in the ground-breaking meeting between Xi Jinping and Ma Ying-jeou in Singapore in November $2015 .{ }^{6}$ Indeed, during the recent election campaign, a number of mainland officials made public statements describing acceptance of the Consensus as the only basis on which future peaceful development of cross-strait cooperation could be guaranteed. ${ }^{7}$

\section{The DPP and Tensions over the One China Principle}

However, the DPP does not and has never endorsed the 1992 Consensus. This attitude is driven mainly by the viewpoint that the principle of one China across the Taiwan Strait is not an acceptable basis for political dialogue, either with mainland authorities in Beijing or with any other international actors beyond. This perspective accords with the DPP's more assertive promotion of a distinctive form of Taiwanese identity, separate from those resident in mainland China and implying that a polity on Taiwan could form the basis for a separate state altogether rather than just a distinct society that would enjoy considerable autonomy the formulation consistently promoted by Beijing. Any future that includes an independent Taiwan is abhorrent to mainland China and numerous analysts across the mainland have restated Xi's ominous warning that 'the earth will shake and the mountains will tumble' were Taiwan to reject the Consensus and be seen to move down a pathway to separatism. ${ }^{8}$

Of course, the DPP is, like most political parties, reflective of a spectrum of views on key issues, representing beneath a single umbrella a range of beliefs from ardent dark green separatists who advocate full independence as the Republic of Taiwan to more flexible lighter-hued pragmatists who are typically willing to engage with Beijing under current constitutional arrangements, whilst still vigorously safeguarding sovereignty. ${ }^{9}$ Tsai herself is no stranger to controversy on the issue of independence. For example, prior to her defeat as 
DPP presidential candidate in 2012, Tsai's policy statements on cross-strait relations and her proposed 'Taiwan Consensus' as a precursor for dialogue with mainland China led to critical commentary in both Beijing and Washington. ${ }^{10}$ During that campaign, she even denied the very existence of the 1992 Consensus formula. ${ }^{11}$ However, since being chosen for a second time as her party's nominee for the presidency, she has sought to steer a middle road of relative moderation (in a DPP context), supporting what she has defined as 'the status quo', being underpinned not only by the constitution of the Republic of China but also by what she refers to as 'Taiwan's most recent democratic will and...20 years of bilateral exchanges and negotiations', although without actually spelling out her position on either the Consensus itself or on the character of any possible future political settlement for Taiwan. ${ }^{12}$

Now elected, the fundamental factors that underpin cross-strait accords cannot be easily sidestepped and considerable care will be needed in the months to come. Beijing has long reiterated what it regards as 'red lines' which would prompt the use of force to resolve the Taiwan question and each one poses clear challenges to a DPP administration. They include rather vaguely defined principles covering any 'moves towards Taiwan independence' or 'indefinite delays in the resumption of cross-strait dialogue on unification' in addition to the more obvious outright declaration of independence by Taiwan. ${ }^{13}$

Yet, there may be room for some optimism. In a roundtable discussion on these issues in the summer of 2015, a DPP specialist on international affairs argued that much had changed within the party since the 2000-08 presidency of Chen Shui-bian. This was a period characterised by turbulent cross-strait relations with DPP policies that included calling referenda on sensitive issues, such as the opening of peace talks with the mainland and applying for UN membership under the name of Taiwan. Chen's behaviour was interpreted 
by Beijing as a tactic to change the underlying framework for dialogue as a precursor to a demand for independence. Whilst neither of these referenda gained sufficient popular support amongst Taiwan's electorate to progress, the political debates surrounding them still caused considerable instability in the triangular relations between mainland China, Taiwan, and the United States, ${ }^{14}$ Now, the DPP maintains that adherence to the status quo will be considerably easier than it was then. The argument put forward is that even dark green supporters in the party are much more realistic about what might now be achievable in dialogue with the mainland, mitigating potential tensions and enabling both sides to seek areas of mutual interest across the strait. ${ }^{15}$ Moreover, the mainland's Anti-Secession Law states that 'consultations and negotiations may be conducted in steps and phases and with flexible and varied modalities' which could act as a useful basis for future talks. ${ }^{16}$

Nevertheless, despite such positive declarations, it remains to be seen how such compromises will actually be constructed in practice. Given how difficult the DPP may find it to agree on any such wording put forward by mainland China, the risk of provoking hostile reactions in Beijing over this fundamental issue do appear to be far greater now than under the previous KMT-led administration. It should also be born in mind that the Chinese Communist Party's (CCP) legitimacy in the mainland as the single guardian of the motherland's unity could illafford to show signs of weakness in dealing with a wayward Taiwanese government unwilling to yield to Beijing's rules of engagement by rejecting the one China principle as agreed under the Consensus. After years of nationalist-inspired rhetoric by mainland politicians, achieving reunification intersects with the CCP's discourse on fundamental concepts such as the protection of Chinese sovereignty and the defence of territorial integrity. In this narrative, Taiwan is depicted by the CCP as 'the last piece of China cut off by foreign imperialists that has not been returned' - a remaining symbol of past humiliations that is yet 
to be finally resolved. ${ }^{17}$ Ensuring an acceptable outcome over the Taiwan issue has become 'a question of regime survival' for the $\mathrm{CCP}$, whereby 'no regime could survive the loss of Taiwan'. ${ }^{18}$

Reunification with Taiwan therefore remains one of Beijing's core national interests. However, the strategy of how best to achieve that end has been evolving over time. ${ }^{19}$ Three broad policy phases can be observed. First, during the Mao era, the focus was on liberation of Taiwan by overt use of force as part of completing the victory of the CCP in the Chinese Civil War, an aim frustrated by direct US intervention through deploying naval forces to the Taiwan Strait after the Korean War erupted and the subsequent signing of a Mutual Defence Treaty with Taipei in 1954. The second phase was led by Deng Xiaoping concurrent with his reform and opening initiatives after 1979. Deng emphasised political objectives, with the aim of achieving reunification through peaceful elite dialogue whilst promoting closer economic ties. This approach broke down under Jiang Zemin during the 1995-96 cross-strait crises over Chinese concerns about Taiwan's transition to an elected presidency and the behaviour of the island's then leader, Lee Teng-hui. The third phase, taken forward by Hu Jintao, involved a more complex multifaceted strategy aimed at the prevention of Taiwan independence through use of hard power resources such as military upgrading and legal justification via the AntiSecession law, whilst at the same time using soft power influences to promote closer economic and cultural integration between the two communities on each side of the strait. This phase accelerated under Ma Ying-jeou's two terms in office, marked by a landmark bilateral trade agreement in 2010, the introduction of direct flights between Taipei and numerous cities on the Chinese mainland (instead of having to transit via Hong Kong), and a growth in two-way tourism.

The assent to power of Xi Jinping has seen a broad-based continuation of Beijing's multifaceted approach, but with some significant adjustments in tone and emphasis. Xi has consolidated power at the top of China's party-state apparatus of government in ways not seen since Mao, and in respect to Taiwan in particular appears to be taking a much more personal, hands-on, interest in cross-strait 
tensions than many of his predecessors did, becoming 'his own teacher on the Taiwan issue' ${ }^{20}$ In particular, $\mathrm{Xi}$ is able to draw on his considerable experience of Taiwan that he acquired during his time working in Fujian province between 1988 and 2002. ${ }^{21}$ Promoting a more assertive approach to cross-strait relations, he has personally tackled head-on the contentious issue of timelines for unification as part of his wider strategy to realise the 'rejuvenation of the Chinese nation', arguing that this objective requires the effort of people on both sides of the Taiwan Strait. ${ }^{22}$ For example, Xi has insisted that 'longstanding cross-Strait political differences will have to be solved step by step eventually, while these problems cannot be passed down from generation to generation' - a statement interpreted to mean that indefinite postponement of reunification is unacceptable. ${ }^{23}$ Despite the distractions of significant economic challenges currently facing mainland China, it would be inadvisable to think that this means any dilution of the importance of Taiwan in the Chinese leadership's priorities.

\section{Evaluating the Prospects for Conflict in the Taiwan Strait}

The possibility of armed assault on Taiwan by mainland troops has never been ruled out by authorities in Beijing. For example, the live-fire exercise carried out by mainland China adjacent to Taiwan-administered Kinmen Island that took place within days of Tsai's election, whilst not in itself particularly serious, is still symptomatic of the underlying tensions in this region that lurk beneath the surface which could readily spark into something much more consequential at any time. ${ }^{24}$ Indeed, last year mainland Chinese troops practiced overrunning a building whose design, colouring and shape bore remarkable resemblance to Taipei's presidential offices, an exercise that caused consternation across Taiwan, fuelling further mistrust towards the PRC ahead of this year's elections. ${ }^{25}$

Argument over the likelihood of war across the Taiwan Strait has been extensive for many years, with the probability of imminent conflict continuing to be an important topic for 
scholars, analysts and politicians alike. ${ }^{26}$ From these debates, a number of key premises stand out. First, that any such armed conflict is one that neither side seeks but for which both sides continue to prepare; second, that the outbreak of direct military action would cause mainland China to incur significant political, economic and military costs; third, that despite these potential costs the mainland has never and will never rule out the use of military force to resolve cross-strait relations; and finally, that the risk of escalation from political tension and provocation to outright armed confrontation can never be eliminated from this unique relationship, despite eight years of détente under the $\mathrm{KMT}^{27}$

It is particularly interesting that analysis of the current military dimension in cross-strait relations shows that the balance of military power and offensive capability may now have fundamentally shifted in favour of Beijing, should conflict actually arise. ${ }^{28}$ Changes in power relations of this kind can impact the security situation in the Taiwan Strait in two main ways: first, they influence the relationship between Beijing and Washington; second, they help to shape the character of dealings between Taiwan and mainland China.

The Obama administration continues to maintain a policy over Taiwan that can best be described as one of strategic ambiguity. ${ }^{29}$ This approach is anchored to the framework of America's own longstanding 'one China' policy that is distinct from Beijing's 'one China' principle, wherein the US government recognises neither 'the PRC's claim over Taiwan nor Taiwan as a sovereign state' ${ }^{30}$ On the one hand, warm words of support extol how Taiwan is 'a vital partner for the United States in Asia' whilst also pointing to the US's ongoing commitment through sales of defensive weapons, assistance with security capacity building, and support for Taipei to participate in international organisations that do not require statehood. ${ }^{31}$ On the other hand, such a discourse is tempered by remarks that seek to deter any 
move towards independence or unilateral changes that alter the status quo and that might jeopardise prospects for further peaceful development.

Washington's primary interest can therefore be seen as the 'maintenance of cross-Strait stability' and the 'peaceful resolution of differences in a manner acceptable to people on both sides of the Strait'. ${ }^{32}$ In pursuit of these goals, the US has been prepared to criticise politicians in Taipei for straying too close to mainland China's perceived red lines whilst at the same time urging both sides to maintain dialogue 'on the basis of dignity and respect after Taiwan's new administration takes office in May'. ${ }^{33}$ Despite rising tensions between the US and China on a number of fronts, such as disputes in the South China Sea and Chinese alleged involvement in cyber espionage, available evidence from after the DPP's election victory suggest that the US government will seek to avoid controversy in cross-strait relations whilst it prioritises other issues with mainland China and will, in all likelihood, continue to maintain the ambiguous nature of its commitments to Taiwan. ${ }^{34}$

The US's role in either a political or military dispute between Taiwan and mainland China is therefore a key one, not just because of the significant US naval presence in the Western Pacific but because the US acts as Taiwan's principal de facto ally under the terms of the Taiwan Relations Act (TRA) - albeit without a formal alliance. The TRA is a piece of US legislation passed in 1979, the year that the US formally switched recognition of what constituted China in diplomatic terms from Taipei to Beijing. The act requires the US president to inform Congress of any perceived threat to the security of Taiwan and to the interests of the US arising from such a threat. However, aside from a specific pledge for the US to continue sales of defensive weaponry to Taipei and the assertion that any attack on 
Taiwan would be considered as a matter of grave concern, the TRA is rather vague in spelling out what any US response would or should be in a future military confrontation. ${ }^{35}$

Direct involvement of US armed forces in a possible conflict between Taiwan and mainland China has never been guaranteed as there is no automatic treaty-based obligation. This ambiguity brings into sharp relief the pressures on political decision-making that might be applied when assessing the costs and benefits of military intervention in support of Taiwan by a US president. These costs can change over time and strategic developments, such as mainland China's enhanced military capabilities in cross-strait terms, could influence outcomes in any risk assessment made. Understanding China's enhanced military capabilities and the associated risk profile that they now present to decision makers in Washington, are therefore vital in forming an accurate appreciation of the region's new power dynamics.

\section{The Balance of Military Power in the Taiwan Strait}

In recent years, there has been much discussion about mainland China's shift from a traditional land power to an assertive sea power. Analysis has focused on the extent to which the country may be following a Mahan-inspired course,${ }^{36}$ seeking to realise ambitions beyond East Asia that directly challenge the current global maritime supremacy of the US. ${ }^{37}$ In fact, an examination of quantitative indicators shows that for many of the key metrics in global military terms - for example, in gross defence spending, and in number of aircraft carriers, destroyers and long-range ballistic missiles - Chinese assets continue to be eclipsed by those of the US. ${ }^{38}$ However, that is rather missing the point, for three reasons: first, the continuing centrality of possible military action over the Taiwan issue in the strategic plans of mainland China's People's Liberation Army (PLA) must be properly understood; second, the 
capabilities of the PLA's latest military systems in this theatre need to be taken into account; and third, the constraints on Taiwan's own defensive position demand careful consideration.

Mainland China's military strategy has long remained focused on improving the PLA's capability to successfully launch and conclude the recapture of Taiwan, acting as "the fundamental driver for development of offensive capabilities in the PLA Navy' and underpinning one of the main planks of the Chinese military's 'new historic missions' policy. ${ }^{39}$ Beijing's most recent defence review, published in May 2015, reiterated these themes by outlining security priorities under the principle of 'active defense', making clear just how important the Taiwan issue is by characterising reunification as 'an inevitable trend in the course of national rejuvenation' ${ }^{40}$ The document also explicitly warned about the threat posed to the future of peaceful development in cross-strait relations by any movement towards the island's independence.

The most recent assessment by the US Department of Defense confirms that 'preparation for a Taiwan conflict with the possibility of U.S. intervention continues to dominate China's military modernization programme'. ${ }^{41}$ In 2015 , total military expenditure by the People's Republic of China was US\$214 billion, having risen from just US\$40 billion in 2004 (expressed in values at the prevailing dollar exchange rate for each year). ${ }^{42}$ Investment has been particularly strong in missile technology, surface-fleet rollout, submarine deployment, aircraft design including stealth fighters and cyber-warfare capabilities. All of this has significantly upgraded the country's military capability to project power across the Western Pacific region and in the Taiwan Strait in particular. In direct comparisons with Taiwan's own resources, the mainland has demonstrably more available to sustain a campaign, by some considerable margin. ${ }^{43}$ 
The principal doctrine for successfully carrying out a military campaign against Taiwan has been anchored on anti-access and area-denial (A2/AD) capabilities, to delay and deter thirdparty involvement whilst PLA forces overwhelm Taiwan's defences. Moreover, in recent years the Chinese have significantly enhanced the development of advanced A2/AD weaponry to a new level of intensity in the deployment of ballistic missiles, land, air and seaborne systems. ${ }^{44}$ In particular, China's unveiling in September 2015 of its anti-ship ballistic missile (ASBM), known as the Dongfeng 21D (DF-21D) or 'East Wind', refutes an attitude prevalent amongst some in US policy circles of 'ASBM denial' about Chinese abilities. ${ }^{45}$ This outlook has been based on the premise that any attempts by China to embrace information-age weaponry would be doomed to suffer industrial-age shortcomings. The assumption behind such an argument was that any Chinese-developed missile would have similar failings to those of past Soviet-era designs and as a result would be no match for the more advanced technology underpinning defences possessed by the US. ${ }^{46}$ Evidence suggests that such a position is now no longer tenable.

Developed on the basis of China's often-overlooked strengths in applied incremental innovation within indigenous high-technology fields across its defence industry, the DF-21D possesses a manoeuvrable warhead for target finding and has precision-guidance capabilities over open seas. This missile has been variously described as China's 'game-changer', as a 'carrier-killer' and as a 'direct threat to the foundations of U.S. power projection in the AsiaPacific' in that it challenges the air-defence strategy of US forces in the deployment US carrier strike groups (CSGs). ${ }^{47}$ Whilst questions do remain about China's capabilities in command, control, communications, computers, intelligence, surveillance and reconnaissance (C4ISR), all of which are seen as a vital input factors in developing necessary sophistication 
in military infrastructure to support the effective use of such a weapon, the DF-21D's potential impact on regional conflict management cannot be overlooked. ${ }^{48}$

Indeed, it would be churlish not to recognise China's capabilities in terms of human capital in science and technology to support putting into place C4ISR competences as part of the introduction of such a missile into general operation. At the very least, China's potential to deploy a weapon of this kind may give pause for thought in Washington. Military deployment in a conflict always carries with it political perils but dealing with a genuine threat to an American CSG could dramatically alter the risk factors for any incumbent of the Oval Office. This does not pre-suppose that a US decision to support Taiwan with direct intervention would not eventually be forthcoming and nor does it ignore the US's technological leadership in being able to deploy effective counter-measures. However, it could still impact decision-making in ways that disadvantage Taiwan in any future conflict with the mainland. Moreover, no longer may the US act with impunity to deploy aircraft carriers to close down Chinese aggression in the ways of the past.

\section{Assessing Taiwan's Strategic Response}

The extent to which scenario building by Taiwan's defence community has had to take account of these developments is spelt out in official documents such as the National Defense Report and the Quadrennial Defense Review produced by the Ministry of National Defense in Taipei. Each one devotes considerable space to outlining the nature of the threat now posed by mainland China's capabilities, whilst simultaneously explaining how Taiwan's countermeasures such as missile defence, air interception, base protection and early warning capabilities can mitigate such threats. ${ }^{49}$ 
Taiwan's strategy is officially known as 'resolute defense and credible deterrence' within a framework referred to as 'hard ROC', whereby the depth of capabilities across the island and into littoral waters is reinforced through the use of multiple assets at a level that is sufficiently strong to impose prohibitive costs on the invader. ${ }^{50}$ In addition to this overarching theme is an emphasis on enabling better systems interoperability coupled with developing more indigenous weapons technology alongside a medium-term objective to deploy a volunteeronly professional fighting force rather than one dependent on drafted full-time service. ${ }^{51}$ Nevertheless, a balanced analysis of Taiwan's position in respect to Chinese deployment superiority in this theatre needs to consider that in the absence of prompt and effective US intervention, successful military defensive action across the island in the face of an assault from PLA forces faces formidable obstacles.

In these circumstances, anything that delays a US decision over intervention - such as a prolonged risk assessment - could have serious implications for Taiwan's defence strategy. This is because one of the island's key defensive rationales focuses on disrupting a Chinese attack for long enough to enable external support of one kind or another to arrive - according to some defence officials in Taipei, for up to thirty days. The implicit assumption is that such help will be from the US. Such an optimistic assessment of Taiwan's capacity to prosecute in-depth defensive responses to a mainland invasion may be the product of a number of wargaming scenarios. However, the military rebalancing of power that now appears to be underway does seem to call into question whether a defensive operation against mainland forces could be sustained for such a length of time. ${ }^{52}$

Taiwan also faces budgetary constraints on crafting future defence strategy. The cost of purchasing the latest imported weapons from the US and elsewhere is considerable and 
Taiwan's economy has been under some strain in recent years as it faces continuing uncertainties in global demand. Figures from Taiwan's Directorate-General of Budget, Accounting and Statistics indicate that year-on-year annual economic growth fell from $3.92 \%$ in 2014 to just $0.75 \%$ in 2015 (the lowest annual growth rate since the global financial crisis), with forecasts for 2016 showing only a slight recovery to an expected $1.47 \%{ }^{53}$ Experience of an economic slowdown and challenges to the island's prosperity may combine to make the purchase of advanced weaponry less of a priority, much to the frustration of some analysts who reiterate the importance of showing that Taiwan 'is serious about its own defense'. ${ }^{54}$

Given all of this strategic uncertainty, the incoming leader faces a number of choices. Whilst a policy of conflict prevention will no doubt continue to be the priority for Taipei under the new administration, there is now a confluence of difficulties facing the newly inaugurated president as she takes office on 20 May 2016. Economic constraints are already in place on Taiwan's ability to spend its way to achieve a militarily effective defence capability, reinforcing the importance of unequivocal support from the US. Political challenges persist over how the DPP should approach the sensitivities of mainland China concerning the 1992 Consensus, which are likely to be fraught and subject to sparks of frustration that always have the potential to escalate.

Nevertheless, politics is the art of the possible. A form of wording over the Consensus could be found, the DPP's more sceptical stance towards mainland China may actually rebuild trust with the electorate to facilitate more rather than less future engagement, albeit on a case-bycase policy basis, and a new president in Washington from January 2017 might firmly indicate US commitments to Taiwan's defence as part of a more muscular restatement of an American pivot to Asia. 


\section{Conclusion}

There does appear to have been a meaningful shift in the balance of military power across the Taiwan Strait in favour of mainland China. Such a development suggests a direct impact on the evolution of cross-strait relations, reshaping the decision-making options for Taiwan and the US in important ways. Conflict is by no means inevitable. Nonetheless, there is now a real possibility that emerging Chinese capabilities could delay or even deter US intervention in a cross-strait confrontation - this directly targets a key plank of Taiwan's defence assumptions. In light of these conditions, what becomes particularly clear is that future stability for Taiwan now rests on finding political solutions with the mainland involving hard bargaining and difficult compromises rather than on attempting to compete militarily with Beijing.

\section{Notes}

\footnotetext{
${ }^{1}$ The status of Taiwan as a political entity is contested. The People's Republic of China (PRC), with its capital in Beijing, argues that the PRC is the internationally recognised
} successor state to the Republic of China (ROC) whose leaders fled to the island of Taiwan in 1949. The PRC regards the administration in Taipei as a renegade province and its continuing existence as an unfinished legacy of the Chinese Civil War. In this article, the terms 'mainland China' and 'Taiwan' are used to describe the two entities on each side of the Taiwan Strait as terms that might be acceptable by all actors involved in these debates. ${ }^{2}$ The KMT is the major party within what is known as the 'pan-blue' spectrum, a loose alliance of those whose political, economic and cultural embrace of mainland China has in modern times been warmer than the more independence-minded 'pan-Green' alliance led by the DPP. A detailed discussion of Taiwan's domestic political evolution and cross-strait 
history is beyond the scope of this article. For a useful primer on this issue, see Steven M.

Goldstein, China and Taiwan (Cambridge: Polity Press, 2015).

${ }^{3}$ Xinhua, 'Anti-Secession Law Adopted by NPC (Full Text)', 14 March 2005.

${ }^{4}$ Taiwan Affairs Office and the Information Office of the State Council, 'The One-China Principle and the Taiwan Issue', <http://www.china.org.cn/english/taiwan/7956.htm>, accessed 20 January 2016, para. 4.

${ }^{5}$ Mainland Affairs Council, Republic of China, '1992 Consensus: The Key to Cross-Strait Peace and Prosperity', July 2015, p.2.

${ }^{6}$ Huileng Tan, 'China-Taiwan President's Meet: Issues on the Table' CNBC, 5 November 2015.

${ }^{7}$ Xinhua, 'Mainland Official Stresses 1992 Consensus on Cross-Strait Affairs', 25 November 2015; Xinhua, 'New Taiwan Leader Must Follow 1992 Consensus: Mainland', 16 August 2015.

${ }^{8}$ For example, see Stephen M Young, 'Cross-Strait Trilateral Conference: Focus on Taiwan's Seminal January 2016 Elections', National Committee on American Foreign Policy, April 2015, pp. 4, 9 .

${ }^{9}$ For an interesting discussion of disagreement across different factions within the DPP prior to the election, see Chris Wang, 'DPP Still Split over Ker's Independence Clause Plan', Taipei Times, 30 December 2013. For a detailed analysis on the role of pragmatists in the DPP's policy formation, see Gunter Schubert, 'Between Strategic Change and Ideological Adjustment: The DPP's China Policy Debate in the Aftermath of the 2012 National Elections' The Taiwanese Political Science Review (Vol. 16, No. 2, November 2012).

${ }^{10}$ See Democratic Progressive Party, 'DPP Chair Tsai Ing-wen's Remarks at Capitol Hill', 15 September 2011, <http://english.dpp.org.tw/dpp-chair-tsai-ing-wens-remarks-at-capitol- 
hill/>, accessed 5 April 2016, paragraph 7. For an official reaction from Beijing to Tsai's long term policy plans during the 2012 campaign, see Xinhua, 'Mainland Says Taiwan Opposition Leader's 10-year policy unacceptable', 24 August 2011. For reporting of negative reactions within the US government to Tsai's approach to cross-strait relations at that time, see Anna Fifield, Robin Kwong and Kathrin Hillie, 'US Concerned about Taiwan Candidate', Financial Times, 15 September 2011.

${ }^{11}$ See this press report from 2011, Lin Cho-shui, 'Life Beyond the 1992 Consensus?', Taipei Times, 5 September 2011, paragraph 5.

12 Taipei Times 'INTERVIEW: Tsai's Cross-Strait Policy to Rest on Democratic Will', 22 January 2016, paragraphs 6, 8. For further analysis of the political implications behind these issues, see Alan D Romberg, 'Consolidating Positions', China Leadership Monitor (No. 48, Fall 2015).

${ }^{13}$ Department of Defense, 'Annual Report to Congress: Military and Security Developments Involving the People's Republic of China', D-117FA69, April 2015, pp. 57-58.

${ }^{14}$ See this article that outlines both Chinese and American concerns over Chen's moves to potentially change the status quo. Tao Wenzhao 'No Support for Chen's "UN Referendum" Plot', China Daily, 31 August 2007.

${ }^{15}$ Roundtable discussion attended by the author at the Department of International Affairs, Democratic Progressive Party, Taipei, 21 August 2015.

${ }^{16}$ Xinhua, 'Anti-Secession Law Adopted by NPC (Full Text)', Article 7.

${ }^{17}$ Taiwan was under Japanese rule between 1895 and 1945 after being ceded by Imperial China under the terms of the Treaty of Shimonoseki that followed Japan's victory in a brief 
war between the two states. See Hardina Ohlendorf, ' The Taiwan Dilemma in Chinese Nationalism', Asian Survey (Vol. 54, No. 3, 2014), p. 475

${ }^{18}$ Susan L Shirk, China: Fragile Superpower: How China's Internal Politics Could Derail its Peaceful Rise (Oxford: Oxford University Press, 2007), p. 182.

${ }^{19}$ For an interesting review of historical tensions in cross-strait relations, see Czeslaw Tubilewicz, 'Cross-Strait Relations and China's reunification prospects', in Czeslaw Tubilewicz (ed), Critical Issues in Contemporary China (New York: Routledge, 2006).

${ }^{20}$ Stephen M Young, 'Cross-Strait Trilateral Conference', p. 8.

${ }^{21}$ Fujian is the province closest to Taiwan and has been at the heart of cross-strait trade links for years. Indeed, the city of Xiamen can be easily seen from the old battlements of Taiwancontrolled Kinmen Island that lies less than two miles offshore from the mainland. See China Daily, 'Fujian is my second hometown, says Chinese President Xi Jinping', 7 November 2014.

${ }^{22}$ China Daily, 'President Xi warns against “Taiwan independence” in any form', 6 March 2016, paragraph 11.

${ }^{23}$ Xinhua, 'Xinhua Insight: First cross-Strait peace forum pools political wisdom', 11

October 2013, paragraph 11. See also Richard C Bush III, 'Decoding Xi Jinping’s latest remarks on Taiwan', Brookings, 17 March 2016.

${ }^{24}$ Faith Hung and Ben Blanchard, 'Taiwan Says China Drills Days after Election "Very Bad News"”, Reuters, 21 January 2016.

${ }^{25}$ Chun Han Wong, 'Palace Intrigue: Chinese Soldiers Storm Replica of Taiwan Presidential Office', Wall Street Journal, 23 July 2015. 
${ }^{26}$ For example, see John F Copper, Playing with Fire: The Looming War with China Over Taiwan (London: Praeger Security International, 2006); Denny Roy, Return of the Dragon: Rising China and Regional Security (New York, NY: Columbia University Press, 2013); Goldstein, China and Taiwan, pp. 168-81.

${ }^{27}$ For a very interesting analysis of possible scenarios on how cross-strait conflict might erupt, see in particular Scott L Kastner, 'Rethinking the Prospects for Conflict in the Taiwan Strait', in Ming-Chin Monique Chu and Scott L Kastner (eds), Globalization and Security Relations across the Taiwan Strait: In the Shadow of China (Abingdon: Routledge, 2015). ${ }^{28}$ Elizabeth Freund Larus, 'Technological Change and China's Naval Modernization: Security Implications for Taiwan', in Paul Irwin Crookes and Jan Knoerich (eds), CrossTaiwan Strait Relations in an Era of Technological Change: Security, Economic and Cultural Dimensions (Basigstoke: Palgrave Macmillan, 2015). See also Goldstein, China and Taiwan, pp. 168-169.

${ }^{29}$ For a interesting analysis of this approach, see Dean P Chen, US Taiwan Strait Policy: The Origins of Strategic Ambiguity (Boulder, CO: Lynne Rienner, 2012)

${ }^{30}$ Shirley A Kan and Wayne M Morrison, 'U.S.-Taiwan Relationship: Overview of Policy Issues' Congressional Research Service, 11 December 2014, p. 4.

${ }^{31}$ Susan Thornton, 'Taiwan: A Vital Partner in East Asia', Remarks made at the Brookings Institution, 21 May 2015, <http://www.state.gov/p/eap/rls/rm/2015/05/242705.htm>, accessed 6 April 2016, paragraph 3.

${ }^{32}$ Kin Moy, 'Trends in the U.S.-Taiwan Relationship', Remarks made at the Carnegie Endowment for International Peace, 3 October 2013, <http://www.state.gov/p/eap/rls/rm/2013/10/213756.htm>, accessed 6 April 2016. ${ }^{33}$ Thornton, 'Taiwan: A Vital Partner in East Asia', paragraph 26. 
${ }^{34}$ Susan Thornton, Testimony of the Deputy Assistant Secretary of State to the House Foreign Affairs Committee Subcommittee on Asia and the Pacific, 11 February 2016. ${ }^{35}$ For detailed analysis of the Taiwan Relations Act, see Goldstein, China and Taiwan, pp. 53-60. For the official US position towards Taiwan, see Department of State, 'U.S. Relations With Taiwan', 12 February 2015, fact sheet, <http://www.state.gov/r/pa/ei/bgn/35855.htm>, accessed 10 January 2016.

${ }^{36}$ Alfred Taylor Mahan (1840-1914) was an influential nineteenth century American military strategist. In 1890, when president of the US Naval War College, he published a book entitled 'The Influence of Sea Power upon History' in which he argued that Britain's then control of the high seas, and the country's naval supremacy compared with European rivals, had enabled the UK to become the dominant global power of that time. He is associated with the concept that in order to become a world power, a nation needs to shift from focusing primarily on land-power military resources to prioritising the development of sea-power capabilities. See Department of State Office of the Historian, 'Milestones: 1866-1898' <https://history.state.gov/milestones/1866-1898/mahan>, accessed 6 April 2016.

${ }^{37}$ There are sharply differing views on the extent to which Mahan's ideas drive Chinese thinking. For a Chinese perspective see Zhang Wei, 'A General Review of the History of China's Sea-Power Theory Development', translated by Shazeda Ahmed, Naval War College Review (Vol. 68, No. 4, Autumn 2015). For an American-centric analysis, see James R Holmes, 'China’s Naval Strategy: Mahanian Ends Through Maoist Means', The Diplomat, 21 June 2013.

${ }^{38}$ See information from the Stockholm International Peace Research Institute (SIPRI) Military Expenditure Database 2015, http://www.sipri.org/research/armaments/milex/milex_database ; Larus, 'Technological 
Change and China's Naval Modernization', p. 50; Giri Rajendran, 'Military Balance Recap:

Defence Spending - When Will China Match US?', speech given at IISS, London, 19

February 2014, <http://www.iiss.org/en/militarybalanceblog/blogsections/2014-

3bea/february-f007/china-military-spending-9c4f>, accessed 10 January 2016; Rosemary

Foot and Andrew Walter, China, the United States, and Global Order (Oxford: Oxford

University Press, 2010), p. 22.

${ }^{39}$ Cortez A Cooper, 'The PLA Navy's "New Historic Missions”: Expanding Capabilities for a Re-emergent Maritime Power', testimony presented before the U.S.-China Economic and Security Review, 11 June 2009, <http://www.rand.org/pubs/testimonies/CT332.html>, accessed 1 April 2016, p. 4.

${ }^{40}$ Information Office of the State Council, 'China's Military Strategy', May 2015, para. 8.

${ }^{41}$ Department of Defense, 'Annual Report to Congress', p. 59.

${ }^{42}$ SIPRI, http://www.sipri.org/research/armaments/milex/milex_database.

${ }^{43}$ See the analyses from China Military Online and the Institute for International and

Strategic Studies for useful background on these trends. China Military Online, 'China's

Fifth-Generation Stealth Fighter Debuts at Dubai Airshow', 9 November 2015,

<http://english.chinamil.com.cn/news-channels/china-military-news/2015-

11/09/content_6761247.htm>, accessed 10 January 2016; Douglas Barrie, 'China’s

Hypersonic Test - Behind the Headlines', Military Balance Blog, 30 January 2014; Christian Le Miére, 'Asia's Competition Beneath the Waves Intensifies', Military Balance Blog, 31 January 2014.

${ }^{44}$ Richard D Fisher Jr and James Hardy, 'Update: China Showcases New Weapon Systems at 3 September Parade', IHS Jane’s 360, 8 September 2015.

45 Andrew S Erickson, 'Chinese Anti-Ship Ballistic Missile (ASBM) Development: Drivers, Trajectories and Strategic Implications', Jamestown Foundation, May 2013, p. 1. 
${ }^{46}$ Ibid.

${ }^{47}$ See Ibid., p. 8; Harry J Kazianis, 'Is China's “Carrier-Killer” Really a Threat to the U.S. Navy?', National Interest, 2 September 2015; Vincent Lanaria, 'China’s Hypersonic Dongfeng 21D Ballistic Missile is an Aircraft Carrier Killer', Tech Times, 23 October 2015.

${ }^{48}$ For example, see Larus, 'Technological Change and China's Naval Modernization', pp. $54-56$.

${ }^{49}$ Ministry of National Defense, ROC, National Defense Report: 2013 (Taipei: Ministry of National Defense, Republic of China, 2013); Ministry of National Defense, ROC, 2013 Quadrennial Defense Review: The Republic of China (Taipei: Ministry of National Defense, Republic of China, 2013).

${ }^{50}$ Ministry of National Defense, ROC, National Defense Report, pp. 75, 85.

${ }^{51}$ Ministry of National Defense, ROC, 2013 Quadrennial Defense Review.

${ }^{52}$ Strategy presentation and roundtable discussion attended by the author with officials at the Ministry of National Defense, Republic of China, Taipei, 17 August 2015. Concerning security policy, there was much debate over just how realistic this thirty-day window might be. See also Goldstein, China and Taiwan, p. 181.

${ }^{53}$ Directorate-General of Budget, Accounting and Statistics, ROC, Latest Indicators, <http://eng.stat.gov.tw/point.asp?index=1>, accessed 6 April 2016.

${ }^{54}$ Peter Enav, 'Planning for the Unthinkable', Thinking Taiwan, 14 August 2015, para. 13. 